\title{
Imprensa homossexual no Brasil na década de 1970
}

\author{
Paulo Roberto SOUTO MAIOR JÚNIOR ${ }^{1}$
}

\section{Resumo:}

Este texto analisa um jornal produzido e destinado em grande medida ao público homossexual, o Lampião da Esquina (1978-1981), que se tornou um dos mais conhecidos periódicos homossexuais do país. O objetivo do artigo é mostrar suas condições de emergência, características, os objetivos a que se destinou e que temas elegeu para abordar em um momento particularmente difícil na história democrática do Brasil, a ditadura militar.

Palavras-chave: Homossexualidades. Ditadura Militar. Lampião da Esquina.

\section{Homosexual press in Brazil in the 1970s}

\begin{abstract}
:
This paper analyzes a newspaper produced and intended largely to the homosexual public, Lampião da Esquina (1978-1981), who became one of the most popular periodicals homosexuals in the country. The objective of this article is to show your emergency conditions, characteristics, goals that was intended and what subjects chose to address in a particularly difficult time in the democratic history of Brazil's military dictatorship.
\end{abstract}

Keywords: Homosexualities. Military dictatorship. Lampião da Esquina.

\section{Prensa gay en el contexto brasileño de 1970}

\section{Resumen:}

Este texto analiza un periódico elaborado y destinado fundamentalmente al público homosexual, el Lampião da Esquina (1978-1981), el cual se convirtió en uno de los periódicos homosexuales más conocidos del país. El objetivo del artículo es mostrar sus condiciones de emergencia, características, los objetivos a los que se destinó y los temas que fueron elegidos para abordar, en un momento particularmente difícil de la historia democrática de Brasil, la dictadura militar.

Palabras clave: Homosexualidades. Dictadura Militar. Lampião da Esquina.

\section{As homossexualidades na imprensa antes do Lampião da Esquina}

Em 2014 um passo importante foi dado para o estudo das homossexualidades no Brasil do período da ditadura civil-militar, com a publicação de Ditaduras $e$ homossexualidades: repressão, resistência e a busca da verdade, organizado por Green $\mathrm{e}$ Quinalha (2014). A produção da obra é sugestiva porque reúne uma série de estudos a respeito de um tema ainda pouco abordado na historiografia brasileira, as homossexualidades (VERAS; PEDRO, 2014), bem como sinaliza para a presença de sujeitos até então pouco conhecidos na historiografia sobre o período da ditadura.

\footnotetext{
${ }^{1}$ Doutor, professor da Universidade Federal do Rio Grande do Norte. E-mail: paulosoutom@gmail.com
} 
Este texto é uma colaboração nesse debate. Aqui não se falará de resistências envolvendo combates diretos, perseguições e torturas. Ressaltarei outras formas de resistência, a que se dá pelas palavras e se exerce em forma de narrativa. Por essas razões, abordo, aqui, um periódico homossexual que circulou no Brasil durante o período militar. Trata-se do Lampião da Esquina, distribuído em todo o país. Mas, antes disso, recuo um pouco para apresentar vetores do que nomeio imprensa homossexual, traçando a emergência do periódico.

O Rio de Janeiro dos anos 1960 é lembrado por eventos culturais que levaram a cidade a ser palco de mudanças sociais e culturais. A expansão geográfica da cidade colaborava para um fluxo maior de pessoas. Seus bares, boates, saunas, teatros ganhavam destaque em muitos lugares do país, atraindo sujeitos de cidades menores, ávidos em viverem longe dos olhares vigilantes da vizinhança, da família, dos colegas de trabalho. Cidades como Rio de Janeiro, São Paulo, mas, também, Recife e Fortaleza, contribuíam para um corte biográfico na vida dos migrantes; fundava-se uma nova vida, tecia-se outra biografia (ALBUQUERQUE JÚNIOR; CEBALLOS, 2004).

Foi no Rio de Janeiro que emergiu O Snob (1963-1969). Segundo Green (2000), $O$ Snob constituiu o mais importante jornal gay publicado até então. Criado por Agildo Guimarães, foi o primeiro jornal impresso e não mimeografado e teve uma duração longa: 1963 a 1969. Seu conteúdo, segundo pesquisa de Costa (2010), versava, inicialmente, sobre homens se vestindo com roupas tidas como femininas.

Naquele momento, segundo Fry e MacRae (1985), os homossexuais sociabilizavam-se pelo binarismo bicha versus bofe, o que equivale, respectivamente, a passivo (que é penetrado na relação sexual) e ativo (aquele que penetra). O bofe não era reconhecido como homossexual porque, na relação sexual, ocupava o papel do homem, daquele que penetra. Isso mostra uma concepção hierárquica das relações homossexuais.

Homossexuais recém-chegados na capital carioca podiam se integrar em grupos de sociabilidades situados na cidade. Entre 1963-1964, destaca-se a existência de nove deles: Turma do Catete, Turma de Copacabana, Turma da Zona Norte, Turma do Leme, Turma OK, Turma da Glória, Turma da Mafalda, Turma de Botafogo e o Grupo Snob. Posteriormente, outros jornais voltados ao público homossexual passam a surgir em diversas capitais do Brasil. Em Salvador, em 1967, passava a circular Gay Society e Gay; em 1970, editavam-se, na mesma cidade, O Tiraninho e Little Darling. No Rio, em 1971, Flor do Mal e Presença (SOLIVA, 2012). Tais iniciativas se diferenciavam do modo 
como as homossexualidades eram concebidas em boa parte da sociedade brasileira, inclusive os escritos médicos, que concentravam o posto de autoridade no assunto.

Acontecimentos impressos, acontecimentos discursivos, acontecimentos que provam uma modificação na história das homossexualidades no Brasil. A circulação, ainda que minguada, de publicações homossexuais, atrelada ao curto tempo de duração, põe relevo sobre um outro tempo, da invenção das homossexualidades por seus próprios sujeitos, quando se tornaram narradores-personagem.

No começo dos anos 1970, as Turmas de homossexuais e publicações começavam a desaparecer. Green (2000) especula o aumento da repressão militar com o Ato Institucional no 5 (AI-5), em dezembro de 1968, como uma das razões. Soliva (2012) arrisca que a ausência sofre influência de redefinições do que seriam as homossexualidades por parte dos próprios grupos.

A América Latina vivia, nesse momento, um período político de tensão em decorrência das ditaduras militares em outros países, como Paraguai, Chile, Uruguai e Argentina. Isso não impediu que redes de resistência homossexual se desenvolvessem. Inaugurava-se, em 1969, na Argentina, o Nuestro Mundo, provavelmente o primeiro grupo homossexual da América do Sul, pontua Perlongher (2008). Em 1971, devido a trocas de correspondências e ideias com o movimento gay norte-americano, o grupo passaria a se chamar Frente de Liberación Homosexual. Sua história é marcada por reivindicações, protestos, redes de contatos internacionais e publicação da revista homossexual Somos, precedida por Homossexuales, de junho de 1973, com apenas uma edição (PERLONGHER, 2008).

Dentre os jornais de menor circulação voltados ao público homossexual, houve o Entender. Na época, nas cidades de Rio de Janeiro e São Paulo, os homossexuais eram conhecidos pelo termo entendido. Uma pesquisa realizada em meados dos anos 1970 pela antropóloga Guimarães (2004) deixa perceber as sociabilidades de um grupo de homossexuais, network, no termo utilizado pela autora, na cidade do Rio de Janeiro, muitos dos quais vindos de Belo Horizonte. Esses rapazes, nos seus depoimentos, destacam o termo entendido como uma forma de se autorreferenciar. O uso do termo também foi constatado em pesquisa de Fry e MacRae (1985).

A historiografia sobre as homossexualidades no Brasil pouca ou ainda nenhuma atenção conferiu a esse periódico e outros tantos. É oportuno conhecê-lo um pouco mais:

Imagem 1 - Jornal Entender, n. 1, p. 1, 24 de julho de 1977. 


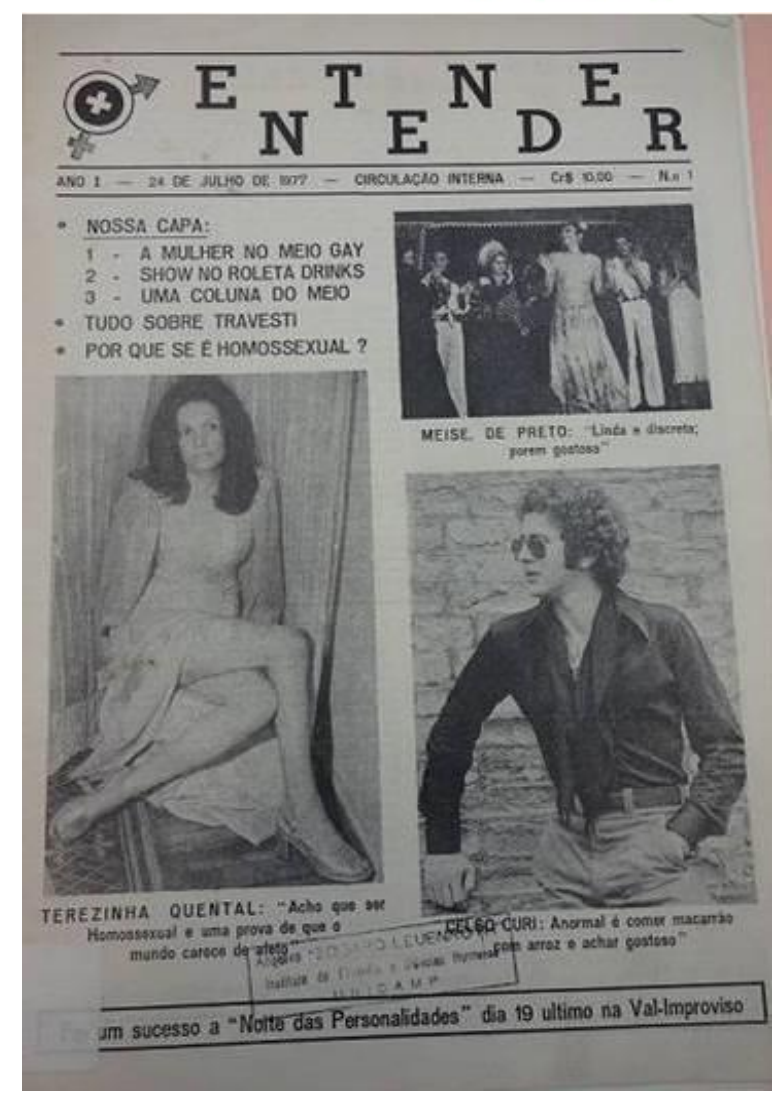

Fonte: Arquivo Edgar Leuenroth/ UNICAMP.

Da capa da edição acima, pode-se inferir que se tratava de publicações de baixo custo, além de apresentar poucas páginas. Não foi possível saber se houve edição experimental ou não. A edição de número 01, datada de 24 de julho de 1977 (Imagem 1), é aparentemente a primeira e, nela, se observa o interesse de atingir um público amplo, dado os diferentes assuntos abordados. A cantora Terezinha Quental fala sobre homossexualidade em uma entrevista do jornal. Simultaneamente, o conhecido jornalista Celso Cury opunha-se à maneira de ver nas homossexualidades uma característica anormal.

Porém, numa frase, também da capa, aparece o seguinte enunciado: "Por que se é homossexual?” (POR QUE..., 1977, p. 1). No texto interno do jornal, explica-se que o homossexual menino "é geralmente o favorito da mãe e recebe dela frequentemente mais atenção do que o próprio pai" (POR QUE..., 1977, p. 5). A mãe teria falhado na sua histórica função de rainha de lar e gestora do futuro da nação. As homossexualidades masculinas são associadas à excessiva aproximação com o feminino. Mas, para o Entender, configuram uma característica culposa; deve-se achar um culpado, afinal, "tradicionalmente a culpa por filhos homossexuais tem sido atribuída quase sempre só às 
mães, mas o pai também pode ser culpado se negligenciar suas responsabilidades" (POR QUE..., 1977, p. 5).

Ao longo dos anos 1970, as homossexualidades passaram a ser tema na grande imprensa, com a publicação de matérias e reportagens em revistas famosas, conforme se pode perceber nos indícios obtidos. Foi o caso da semanal Manchete, na edição de novembro de 1975. "Uma pesquisa Manchete/Ibope, no Rio e em São Paulo, e uma pergunta: Homossexualismo?" dava título à matéria. O objetivo era colocar em discussão a situação dos homossexuais no Brasil, notadamente no eixo Rio-São Paulo. A matéria começava trazendo lugares de encontros. Mencionava a famosa boate paulista Medieval, seu salão ornamentado com armaduras de batalhas medievais, cenário onde "cerca de mil homens" dançavam. Mulheres também frequentavam o lugar, mas preferiam a boate Danny. O Posto 6, na praia de Copacabana, servia "de encontro de homossexuais de ambos os sexos, à sombra das palmeiras e à refrescante brisa do mar" (UMA PESQUISA..., 1975, não paginado).

Parece, entretanto, que o objetivo da revista não foi apenas falar da homossexualidade. Possivelmente, foi obrigada a tratar do tema devido a uma pesquisa realizada pelo Instituto Brasileiro de Opinião Pública e Estatística (IBOPE) com cerca de duzentas pessoas nas cidades de Rio de Janeiro e São Paulo. Ao fim da matéria, após trazer à baila os estudos de Freud e afirmar que a prática não conta com punição no sistema penal brasileiro nem na Constituição Federal, traz alguns dados:

[...] 94\% dos entrevistados que têm filhos(as) com mais de 15 anos procurariam conversar com eles(as), caso suspeitassem um dia que são homossexuais; $88 \%$ dos pais procurariam levar os filhos a abandonarem o homossexualismo, se descobrissem que eles o estivessem praticando, contra $11 \%$ que não tomariam aquela atitude; $85 \%$ dos pais levariam o filho ao médico [...], $28 \%$ aceitariam uma pessoa homossexual integralmente como ela fosse, $26 \%$ a aceitariam como amiga mas não a receberiam em casa, $20 \%$ procurariam afastar-se dela e $14 \%$ não conseguiriam ficar à vontade diante dela mesmo que se esforçassem para isso, 55\% não empregariam homossexuais em seus empregos (UMA PESQUISA..., 1975, não paginado).

A revista opta por escrever uma matéria de seis páginas sobre o tema em pleno ano de 1975, ora tentando esclarecer possíveis causas biológicas para a prática, ora destacando ainda o processo de rejeição aos desejos homossexuais de parte dos paulistas e cariocas.

Essa reportagem possivelmente ganhou direito à existência como consequência do aumento de locais de sociabilidades para o público homossexual no Rio de Janeiro e em São Paulo. A cena cultural do início dos anos 1970 foi marcada, também, por 
androginia e travestismos. O conhecido cantor e compositor Caetano Veloso voltava do exílio, fazendo shows vestido de Carmem Miranda; Ney Matogrosso integrava um grupo chamado Secos e Molhados, mesclando peitoral peludo com maquiagem e roupa feminina. Nas experiências andróginas, houve, ainda, destaque para um outro grupo da época, os Dzi Croquetes. Manifestações culturais desse tipo colocavam em questão outras maneiras de lidar com o corpo.

As modificações vividas na sociedade brasileira naquele momento se deram também na disputa pela cidadania no espaço público. Grupos feministas, por exemplo, passaram a tocar na questão da contracepção, do aborto, do prazer da mulher na relação sexual, do direito ao divórcio, temas considerados tabus, uma vez que colocavam em xeque o modelo social destinado à mulher, até então criada para ser dona de casa e mãe de família.

No mesmo período, a quebra do regime democrático nos países do Cone Sul Argentina, Uruguai e Chile -, além do Brasil, restringiu a entrada em cena de alguns movimentos sociais. Afinal, esses regimes, "além de serem antidemocráticos e de instituírem formas de apropriação de riquezas altamente hierarquizadas, eram conservadores, moralistas e antifeministas" (PEDRO; WOLFF, 2011, p. 400).

Em paralelo, veículos de imprensa passavam a abordar questões relativas aos homossexuais. Foi o caso do jornal popular Última Hora, que, em 1976, passou a levar ao público a Coluna do Meio, escrita pelo jornalista Celso Cury, direcionada ao público homossexual, e que trazia informações de festas voltadas ao público homossexual, bem como notícias do movimento gay norte-americano. A coluna existiu entre 1976-1979, quando sofreu censura e levou Cury a ser processado por ofensa à moral e aos bons costumes pela Lei de Imprensa (RODRIGUES, 2010), então em vigor.

No ano de 1978 se tornava comum a circulação de uma imprensa nanica ou alternativa, caracterizada por ser uma produção de baixo custo, muitas vezes caseira, e, que, geralmente, tocava em questões pouco debatidas pela grande mídia. Parte dessa imprensa era ligada aos grupos de esquerda, cujo objetivo era colocar em debate assuntos referentes às greves de trabalhadores, à situação social das mulheres e dos negros.

Um jornal que passou a circular em abril de 1978 e ficou conhecido em diversos lugares do Brasil foi o Lampião da Esquina. Distribuída na maior parte do país, a publicação podia ser adquirida em bancas de revistas, livrarias e, também, por meio de assinaturas pessoais. No transcorrer de sua existência, o jornal passou a oferecer o serviço 
de assinaturas e, dessa forma, em embalagens discretas, conseguiu atingir um público mais amplo em quase todo o Brasil.

Parte da historiografia brasileira costuma chamar esse momento de "nova era" nas palavras do antropólogo MacRae (1990), período caracterizado pela conquista de uma identidade reivindicatória para determinados grupos em um momento marcado pela efervescência política.

Com o Lampião da Esquina, questões voltadas aos homossexuais passam a ser discutidas em suas edições mensais. De acordo com os historiadores Albuquerque Júnior e Ceballos (2004, p. 129), foi "um momento, portanto, em que no campo da mídia, especialmente da mídia impressa, novas temáticas estão emergindo e novos sujeitos sociais começam a ser construídos".

Os discursos dos jornais da imprensa nanica proporcionaram a visibilidade dos sujeitos dos quais se dispunham a falar e discutiam a questão dos direitos sociais igualitários para esses grupos. Por isso, seus textos incentivaram a construção de um movimento organizado de atuação pública e, simultaneamente, se preocuparam em criar mecanismos que permitissem a emergência de novas maneiras de lidar com a condição de oprimidos (GREEN, 2000).

\section{A emergência do Lampião da Esquina}

O Lampião da Esquina começou a ser pensado não muito tempo antes de sua fundação. Em 1977, houve uma reunião no apartamento do pintor Darcy Penteado (19261987). Compareceram ao encontro alguns jornalistas, artistas e intelectuais do eixo Rio de Janeiro-São Paulo. O objetivo da pauta era reunir textos para uma antologia gay latinoamericana. A obra seria organizada por Winston Leyland, que editava um importante jornal norte-americano, o Gay Sunshine Press, em São Francisco (Califórnia). Na mesma reunião, surgiu a ideia de editar um periódico mensal destinado ao público brasileiro que discutisse homossexualidade e abordasse outros temas (TREVISAN, 2007).

A equipe do jornal era composta por Darcy Penteado, artista plástico e literato conhecido especialmente na região sudeste do país; João Silvério Trevisan, escritor que começava a ganhar destaque, sobretudo devido à publicação de Interlúdios em San Vicente (testamento de Jônatas deixado a David), livro de contos publicado em 1976 pela Editora Brasiliense; Peter Fry, que tinha chegado da Inglaterra para trabalhar na Universidade Estadual de Campinas (UNICAMP) e, mais tarde, passaria a figurar como um conhecido nome da Antropologia; Aguinaldo Silva, também escritor e jornalista 
profissional com experiência em redações de notáveis periódicos brasileiros, a exemplo de Última Hora, do jornalista Samuel Weiner; Antônio Chrysóstomo, que também trabalhava como jornalista; Jean Claude-Bernadet, professor da Universidade de São Paulo. Além desses nomes, a redação contou com a participação de Clóvis Marques, jornalista; Francisco Bittencourt, jornalista e poeta; Gasparino Damata, jornalista e escritor.

O lançamento do jornal, destacou Trevisan (2007, p. 338-339), certamente foi "fato quase escandaloso para as pudicas esquerda e direita brasileiras acostumadas ao recato, acima de tudo. [...] Tratava-se de um jornal que desobedecia em várias direções”. Em abril de 1978, o Lampião da Esquina estava circulando em muitas cidades do país. De acordo com Silva (2014), o jornal chegou a vender 25 mil cópias. ${ }^{2}$

Em formato tabloide e em cores, chegou ao público dividido em sete seções: Opinião, Literatura, Reportagem, Tendências, Ensaio, Esquina e Cartas na Mesa. Posteriormente, na quinta edição, passou a ser inserida a seção Bixórdia, e, mais tarde, a Troca-Troca, com o objetivo de colocar em contato leitores de diferentes regiões do país. Não era por acaso, portanto, que, nos textos publicados nesta coluna, os leitores apresentavam-se se descrevendo corporalmente e apresentando traços de suas personalidades e preferências sexuais.

Nas páginas do Lampião, os leitores podiam encontrar informações sobre filmes, dicas de livros, notícias do movimento homossexual internacional, especialmente norteamericano, que aparece com certa exaltação ${ }^{3}$ em entrevistas com celebridades homossexuais ou não da época, além de uma sessão de cartas escritas pelos leitores.

Todas as seções abordavam diversos temas, o que deixa claro o objetivo do Lampião de atingir um público diversificado. Tratou das homossexualidades em geral, pois um de seus objetivos era criar outros significados a partir da autoafirmação, mas soube, igualmente, mencionar o movimento feminista e o movimento negro sem deixar de lado os defensores do meio ambiente e a questão indígena.

A realização do jornal só foi possível devido ao aprimoramento das técnicas de impressão do momento, como a implantação, por exemplo, do método off-set de

\footnotetext{
${ }^{2}$ Há uma entrevista com o escritor Aguinaldo Silva, no canal on-line Resistir é preciso, em que essa característica é destacada (SILVA, A., 2014).

${ }^{3} \mathrm{O}$ Lampião de Esquina recebeu influências significativas do movimento homossexual norte-americano. Segundo Trevisan (2007), um dos editores, o jornal se assemelhava ao "gay consciousness raising group" americano, visando a uma identidade como grupo social. Acrescenta-se que alguns editores do Lampião mantinham correspondências constantes com grupos norte-americanos como o Gay Liberation Front (TREVISAN, 2007).
} 
impressão a frio, criado pelos americanos nos anos 1950 e permitindo tiragens mais longas (RODRIGUES, 2010).

Certamente, a ambiguidade do título chamou a atenção dos leitores, pois sugeria a iluminação de um espaço escuro, remetendo, no caso dos homossexuais, à ideia da obscuridade do universo homossexual e da clandestinidade de suas relações, além de, em uma segunda hipótese, estar diretamente ligada à atitude dos michês, ${ }^{4}$ que, no final dos anos 1960, começaram a se postar nas ruas do centro de São Paulo e do Rio de Janeiro e de outras capitais brasileiras à espera de "clientes" e de suas propostas sexuais. A palavra lampião é também uma alusão provocativa à figura do mítico cangaceiro Lampião, símbolo, por excelência, da masculinidade e da virilidade, sobretudo no Nordeste brasileiro.

O jornal, ao longo de suas trinta e sete edições, tocava em diversos assuntos; isso não significava, porém, dizer que houve uma divisão equivalente entre as produções dos seus escritores. Apesar de produzido no Rio de Janeiro, havia a sucursal de São Paulo. A carioca era comandada por Aguinaldo Silva e a paulista, por João Silvério Trevisan. Entre eles ocorreram algumas discordâncias entre o que deveria ser prioridade ou não de o Lampião. Aguinaldo Silva desejava uma publicação com fins mais comerciais; Trevisan preferia um jornal com viés mais político e militante.

Era comum encontrar no Lampião entrevistas com autores homossexuais estrangeiros já consagrados, como a realizada com Wiston Leyland, e, também, traduções de textos estrangeiros que abordavam criticamente a questão das homossexualidades e de outros movimentos, a exemplo do feminista e negro. A estratégia, seguramente, buscava conferir legitimidade à publicação.

Não foi apenas pelo seu ineditismo, mas, sobremaneira, pela qualidade das matérias que publicava, que o Lampião da Esquina conseguiu chamar a atenção da grande mídia. Por que o lançamento de um jornal escrito e destinado majoritariamente ao público homossexual virou notícia na época? Um desses periódicos foi a revista Istoé, que noticiou da seguinte maneira o lançamento do jornal:

Maio é o mês das mães, agosto é mês dos pais, abril passa a ser, a partir de agora, o mês do homossexual brasileiro. Lampião saiu da sombra, sério,

\footnotetext{
${ }^{4}$ Essa hipótese se baseia na obra de Perlongher (2008), que estudou a prostituição na cidade de São Paulo. Seu trabalho, defendido como dissertação de mestrado e publicado nos anos 1980, tornou-se uma referência nos estudos de sexualidade e desejo. Talvez uma das razões esteja nas fontes, ao entrevistar clientes, michês, entendidos, um dos termos usados na época para se referir aos homossexuais. Nas entrevistas, identificou que a constituição identitária desses sujeitos ocorre de acordo com determinadas situações.
} 
provocador - e é possível que, de 1978 em diante, nunca mais as coisas sejam como antes. Lampião é um novo jornal gay, mensal, tabloide, nanico, lançado numa maratona de coquetéis, shows, churrasco, abraços, comedorias e comentários maliciosos. [...]

A julgar pelo fato que ocorreu em São Paulo, porém, é conveniente advertir que não se deve esperar por comemorações exageradamente estrepitosas. Os senhores do Conselho Editorial do Lampião são professores universitários, artistas, jornalistas do porte de Aguinaldo Silva (que funciona como um coordenador de redação), Jean-Claude Bernadet, Darcy Penteado, José Silvério Trevisan, Peter Fry. Portanto, não se deve confundir o crime de intelectualidade gay do país com outras manifestações (e até publicações) que tenta glamurizar o travesti ou promover o mercado do sexo homossexual [...]. Apesar desse incomum esforço de proselitismo, tudo indica que Lampião acabará se dirigindo menos a uma clientela gay ampla e muito mais ao clube restrito e multissexual, o que consome a imprensa alternativa. Então, por que mais um nanico? Evidentemente, esta dúvida se colocou para os editores do jornal desde o primeiro momento em que se reuniram, em novembro do ano passado, para traçar o "compromisso histórico dos não-alinhados". Por que mais um nanico, se pelo menos no eixo São Paulo-Rio circula mais de uma dezena de publicações alternativas?

"O homossexualismo não costuma ser considerado um assunto prioritário", explica Aguinaldo Silva. "Em nome dessas prioridades, o assunto acaba sendo simplesmente esquecido. Além do mais, Lampião se propõe a discutir qualquer tema, levantar qualquer problema, sem censura interna, aceitando colaborações não apenas de homossexuais, mas também de outras pessoas cujo comportamento sexual não coincidia como o nosso."

Aguinaldo e seus companheiros têm um desabafo especial contra uma esquerda cabloca "que oscila da apatia ao desprezo" em relação às reinvindicações dos homossexuais e de outras minorias "oprimidas pelo machismo e pela violência da sociedade brasileira". Para Aguinaldo, ao relegar o problema gay à condição de "questão não-prioritária", a esquerda está, no fundo, fazendo "o jogo do establishment". E mais do que isso: revelando "seu próprio puritanismo". "É sintomático que os nanicos adotem abertamente uma política de boicote ao movimento homossexual", afirma Aguinaldo Silva (HATOUM, 1978).

O Lampião foi tema de duas páginas em uma revista que ocupava lugar de destaque na imprensa brasileira, a Istoé. Além do texto, havia uma foto do coquetel de lançamento do jornal na Livraria Cultura, na Avenida Paulista, em São Paulo. Trata-se de uma fotografia memorável porque contém boa parte dos jornalistas que formavam o Lampião, vinculando o periódico diretamente entre eles e à homossexualidade.

A contestação cultural no campo da sexualidade, intensificada com o movimento feminista da segunda metade da década de 1970, ocorreu em paralelo com o desenvolvimento de uma subcultura gay e pessoas se relacionando com outras do mesmo sexo. Elas passam a compor outras cenas da sociedade, provocando uma série de mudanças na contestação de valores estabelecidos. Simultaneamente, no fim dos anos 1970, constituíram-se grupos de militância com o objetivo de reivindicar um discurso, uma voz que possibilitasse aos homossexuais um novo lugar social. 
Um dos objetivos do Lampião ao longo de sua trajetória foi o de tentar modificar o difícil cotidiano dos homossexuais brasileiros. Talvez a proposta e o objetivo do Lampião tenham sido bem recebidos porque seus editores, parte significativa autodeclarada homossexual, sentiam a dificuldade que era a sociabilização, as experiências de lidar com preconceitos e desejos proibidos, gerando fraturas afetivas que poderiam se prolongar por muitos anos, especialmente no seio da família. Isso ocorreu, por exemplo, com o escritor Trevisan, que, em uma entrevista, chegou a declarar que a difícil relação com o pai teria por causa a sua homossexualidade (SILVA, C., 1998).

Em pesquisa realizada no Arquivo Edgar Leuenroth, foram consultadas as cartas enviadas de vários lugares do Brasil para o grupo Somos, de São Paulo. A leitura dessas cartas permite perceber o estado de tensão vivido pelos homossexuais no seio de seus núcleos familiares. Os relatos evidenciam a dificuldade de se assumir homossexual, das brigas com os pais, da saída imediata de casa após a descoberta da homossexualidade. Por todas essas dificuldades é que quase todos desejavam deixar suas cidades para viver nos grandes centros urbanos, como Rio de Janeiro e São Paulo, cidades nas quais não apenas encontravam outros homossexuais, como, também, podiam viver com um pouco mais de liberdade.

Segredo, disfarce, tensão, medo, pânico, expectativas, temor, lágrimas, dor, ressentimento, suspeita, agressão, assédio eram características da vida de muitos homossexuais. Penteado (1980) não deixou de tocar nessa questão:

\footnotetext{
Portanto, o paternalismo é um princípio igualmente comprometido, como vários outros, para um entendimento da homossexualidade, porque prevê em si um sentimento de comiseração, camuflando a eterna jogada do dominador sobre o dominado. E isto a nós, homossexuais, absolutamente não interessa mais! É preciso deixar bem claro também, que a análise científica atual feita sobre a nossa opção sexual não nos perturba nem nos acrescenta em nada, a nós homossexuais conscientizados, porque a nossa cabeça, a partir do momento da conscientização, já superou traumas, sentimentos de culpa, autonegações e toda aquela baboseira mental de que os psicanalistas insistem em nos curar; e já partiu igualmente para coisas bem mais sérias e práticas, como a nossa definição pessoal e coletiva como integrantes de uma sociedade, ou a conquista consequente de nosso espaço vivencial (PENTEADO, 1980, p. 12).
}

O que está em jogo no discurso de Penteado (1980) é um grito pela existência, uma voz que vem dizer, escrever e registrar que os homossexuais estão presentes, embora os vários discursos contrários lhes tentassem negar voz e existência.

Se, por um lado, grita-se contra uma relação de opressão, do dominador versus o dominado, por outro lado, reafirma-se um binarismo característico do emergente 
movimento homossexual daquele momento: o da homossexualidade versus heterossexualidade. Nesse sentido, o discurso de Penteado (1980) pode ser considerado como uma tentativa de ruptura do modo como os homossexuais eram percebidos no país até então. Seu texto convida à luta, sobretudo ao combate das ideias dos estudos médicos que tentavam já, à época, encontrar indícios de uma alteração genética constituidora das homossexualidades. Paralelamente às homossexualidades, deveriam focar na autoafirmação, conquistando, conforme destaca, um lugar na sociedade: o de que existem e clamam por atenção em meio a uma sociedade que reconhece como normais e corretos apenas os comportamentos heterossexuais.

Naquele momento, homossexuais que entrassem em contato com o Lampião da Esquina deixavam claro seu espanto, mormente no aspecto da novidade: um jornal homossexual, isto é, escrito por e para esse público. Várias cartas publicadas no mensário permitem essa reflexão. Cartas de todo o país chegavam à redação falando da sensação de se encontrar com as páginas do Lampião. Assim fez Edilson Fernandes, da cidade de Assun, no Rio Grande do Norte. Segundo Fernandes (1978, p. 17), “negam, gritam e ela existe, e é um fato real, concreto e persistente. É a vida que nasce, chora, ri, sofre, é gente...".

Outra estratégia de conscientizar a população era destacando situações de preconceito vividas pelo público homossexual em todo o país. O jornal abordava as difíceis condições de preconceito e vulnerabilidade social que os homossexuais enfrentavam cotidianamente e, sempre que possível, convidava entrevistados a expressarem-se com relação ao lugar que a homossexualidade ocupava na sociedade. Em uma entrevista sobre essa questão, a cantora e compositora Leci Brandão destacou:

A gente já é marginalizada pela sociedade. Então, a gente se une, se junta, dá as mãos. E um ama o outro sem medo, sem preconceitos. É um negócio maravilhoso que estou curtindo de cabeça realmente. É o mais produtivo mergulho que eu já vi em mim mesma e na vida (BRANDÃO, 1978, p. 11).

Ora, a menção ao preconceito é indício de que essa palavra passava a circular e estava diretamente associada a uma luta dos homossexuais. Eles estavam aparecendo na sociedade, mostrando-se como homossexuais e reivindicando o direito de serem aceitos.

A fala de Leci Brandão direciona para uma época na cultura brasileira em que essas vozes discriminadas tentavam afirmar suas identidades sexuais e o Lampião da Esquina constitui-se em um dos mais expressivos canais para vazão desse desejo. Talvez 
esse jornal tenha sido o primeiro canal de confissão pública da homossexualidade no Brasil, uma vez que se preocupava em colocar em questão constantemente a visibilidade homossexual, destacada com o uso do termo "assumir-se", contribuindo, assim, para a emergência do dispositivo de confissão das homossexualidades no Brasil (SOUTO MAIOR JÚNIOR, 2015).

O jornal tocava em um ponto estruturante nas subjetividades dos homossexuais. Sobrepor-se à tristeza, e acreditar no alívio que a revelação, o assumir-se homossexual traria às suas vidas. Isto explica boa parte do que se tem escrito acerca dessa temática nas últimas décadas. Spencer (1996) sugere que a felicidade para homossexuais esteve, muitas vezes, associada a um outro lugar, não o da origem, aquele vivido diariamente pela tensão da revelação ou descoberta do seu desejo, mas, sobretudo, a um espaço criado e recriado longe e distante, e compartilhado com uma nova família, na qual os parentes passam a ser os amigos.

É oportuno esclarecer, entretanto, que este espaço acaba por criar, em algumas geografias, o conhecido "mundo gay". Constantemente os que migravam do interior para as grandes cidades eram movidos pelo desejo de encontrar pessoas com desejos semelhantes e lugares para se socializarem. Se, no hemisfério norte, os espaços para homossexuais eram Paris, Nova York, São Francisco, Londres, Amsterdam, Berlim, no Brasil, os estudos apontam para o Rio de Janeiro e São Paulo, mas, também, Recife, Salvador e Fortaleza (PARKER, 2002).

A questão da fuga para a cidade ou mitologia da cidade, expressão usada por Eribon (2008), relaciona-se a um exílio para outras cidades, estados, e, até mesmo, outros países. O que não exclui a existência de gays em lugares do interior, apesar de, historiograficamente, ser difícil estudar e contar essas histórias pela ausência de fontes, à exceção de cartas e diários, possivelmente destruídos pela família quando o parente morre.

Capas de algumas das edições passavam a explicitar cada vez mais o caráter também militante do jornal: 
Imagem 2 - Lampião da Esquina, Rio de Janeiro, setembro, 1979.
Imagem 3 - Lampião da Esquina,

Rio de Janeiro, janeiro, 1980.

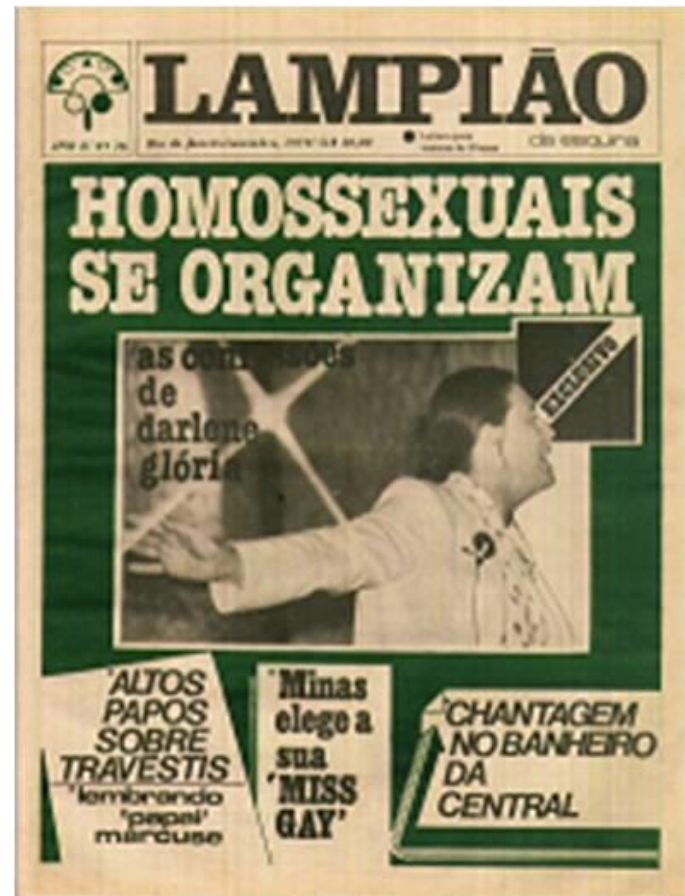

Fonte: Acervo Grupo Dignidade. .

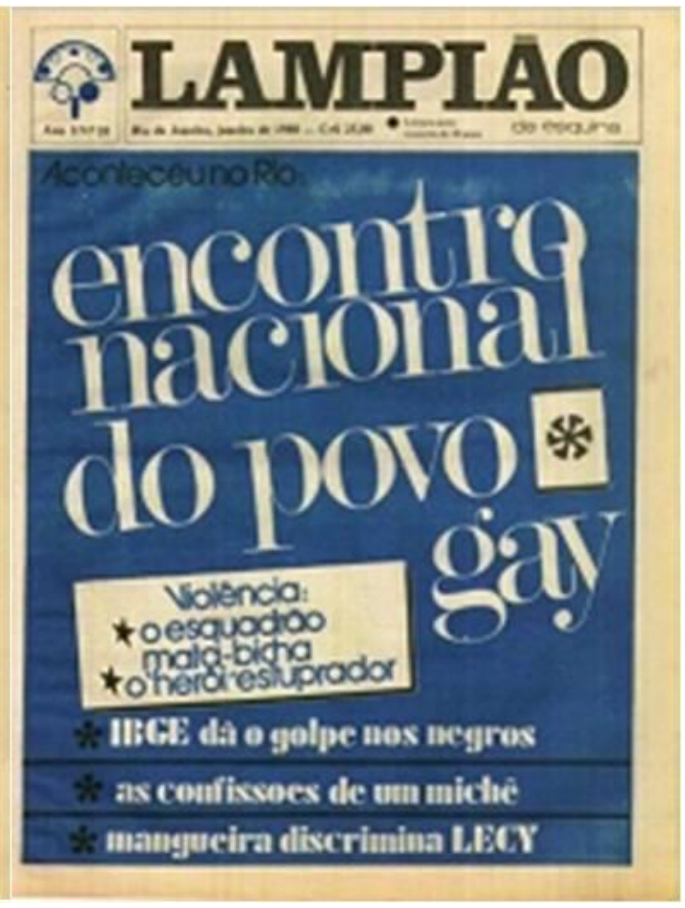

Fonte: Acervo Grupo Dignidade.

Na Imagem 2, edição 16, a capa ilustra o que será tratado. Primeiro, deixa claro qual é o tema principal da edição: associação de homossexuais visando a algumas questões. Segundo, a palavra organizam, utilizado na oração, remete a um campo de luta e disputa que foi o movimento homossexual da primeira onda, o que surge no final dos anos 1970, tendo no Lampião da Esquina um dos seus principais interlocutores. A reportagem da capa destaca os grupos de homossexuais que estavam surgindo no país, como foi o caso do Libertos, de Guarulhos, que, em setembro de 1979, dava seus primeiros passos. Essa edição também destaca o grupo Somos, trazendo entrevistas com alguns membros, dentre os quais, Eduardo, Ricardo e Teka.

Na Imagem 3, é importante perceber que a chamada principal ocupa boa parte do espaço da capa. A ideia de um encontro nacional fornece uma dimensão de um grande e significativo evento com a participação de pessoas de diferentes estados. A palavra gay, usada de acordo com a língua inglesa, é outro ponto de destaque. Algumas pessoas ligadas ao movimento eram contrárias à utilização da palavra no original, em inglês, por entender 
que a realidade dos/das homossexuais norte-americanos/as era substancialmente diferente dos/das brasileiros/as.

Trata-se da edição 20, de janeiro de 1980, e traz uma reportagem do Encontro Nacional do Povo Gay, ocorrido em 16 de dezembro de 1979 na Associação Brasileira de Imprensa do Rio de Janeiro. De acordo com a matéria, era o primeiro encontro dos/das homossexuais militantes com a presença de 60 pessoas vindas de várias cidades: São Paulo, Brasília, Guarulhos, Belo Horizonte e Rio de Janeiro. Entre os presentes, havia o descontentamento com o nível de machismo e preconceito da sociedade brasileira, o que colaborava para manter os homossexuais no gueto, trancados em casa, escondidos, quase sem direito à vivência e aparição pública (MICCOLIS, 1980).

$\mathrm{O}$ encontro foi significativo pelo número de participantes e de grupos homossexuais que vinham surgindo no país após o nascimento do Lampião da Esquina. Percebe-se como as matérias divulgadas no Lampião, os temas de que tratava, as notícias do ativismo homossexual então emergente colaboravam na construção de novos grupos. As demandas do evento incluíram o combate ao "homossexualismo" visto como doença mental. O que essas duas capas do Lampião propõem é mostrar que os/as homossexuais estavam começando a se organizar na busca por direitos. Quando o jornal concede um lugar discursivo ao movimento homossexual, está, necessariamente, instituindo essa questão no cotidiano dos leitores, criando um campo de discussão até então ausente e oferecendo um lugar de debate por meio de suas páginas.

\section{Um campo de possibilidades}

Alguns estudiosos têm sido unânimes em demonstrar a importância do jornal Lampião da Esquina no movimento homossexual brasileiro. Simões (2009) é um deles. Para o antropólogo, tanto o Lampião quanto o grupo Somos, de São Paulo, são marcos de uma politização e reivindicação de direitos por parte dos homossexuais brasileiros. Simões (2009), ao problematizar a configuração identitária do movimento naquele primeiro momento, mostra as tensões vividas tanto no Lampião quando no Somos, no projeto de construção de uma identidade homossexual devido a um debate travado, na época, sobre categorizações e classificações homossexuais.

A descrição do jornal aqui apresentada e a análise de algumas temáticas por ele selecionadas buscaram mostrar a importância do Lampião da Esquina no início do movimento homossexual brasileiro em busca de reconhecimento social e na luta pelos direitos civis. 
Muitas das pautas e reivindicações propostas pelo atual movimento Lésbicas, Gays, Bissexuais, Travestis, Transexuais e Transgêneros (LGBTTT) (OLIVEIRA, 2012) tiveram no Lampião um dos seus primeiros defensores. Naquelas páginas, não se noticiavam apenas informações sobre questões das minorias; suas matérias destacavam as possibilidades de resistência a um silenciamento das homossexualidades no Brasil, muito presente até 1978 .

Nesse sentido, o estudo do Lampião da Esquina aponta diretamente para questões ligadas aos direitos humanos e à luta por uma sociedade mais justa, igualitária e sem preconceitos.

Os temas abordados pelo Lampião floresceram, e se, hoje, diversos grupos organizados de militantes homossexuais lutam, nos mais longínquos rincões do Brasil, convém não esquecer que foi graças aos jornalistas e colaboradores que fundaram e dirigiram os destinos do Lampião até seu fechamento, em julho de 1981. Seu estudo, no campo historiográfico, é igualmente importante para que se possam perceber as transformações e os sonhos dos/das homossexuais brasileiros/as.

\section{Referências}

ALBUQUERQUE JÚNIOR, Durval Muniz de; CEBALLOS, Rodrigo. Trilhas urbanas, armadilhas humanas: a construção de territórios de prazer e de vivência da homossexualidade masculina no Nordeste brasileiro dos anos 1970 e 1980. In: SCHPUN, Mônica Raisa (org.). Masculinidades. São Paulo: Boitempo; Santa Cruz do Sul: EDUNISC, 2004. p. 129-150 .

BRANDÃO, Leci. Lampião da Esquina, Rio de Janeiro, p. 11, nov. 1978.

COSTA, Rogério da Silva Martins da. Sociabilidade homoerótica masculina no Rio de Janeiro na década de 1960: relatos do jornal O Snob. 2010. Dissertação (Mestrado em Bens Culturais e Projetos Sociais) - Centro de Pesquisa e Documentação de História Contemporânea do Brasil, Fundação Getúlio Vargas, Rio de Janeiro, 2010. Disponível em:

https://bibliotecadigital.fgv.br/dspace/bitstream/handle/10438/6564/CPDOC2010Rog\%c 3\%a9rioSMartinsCosta.pdf?sequence=1\&isAllowed=y. Acesso em: 11 dez. 2019.

ERIBON, Didier. Reflexões sobre a questão gay. Rio de Janeiro: Companhia de Freud, 2008.

FERNANDES, Edilson. [Carta do leitor]. Lampião da Esquina, Rio de Janeiro, p. 17, set. 1978 .

FRY, Peter; MAcRAE, Edward. O que é homossexualidade. São Paulo: Brasiliense, 1985. 
GREEN, James. Além do Carnaval: a homossexualidade masculina no Brasil do Século XX. São Paulo: UNESP, 2000.

GREEN, James; QUINALHA, Renan (org.). Ditadura e homossexualidades. São Paulo: EDUFSCAR, 2014.

GUIMARÃES, Carmem Dora. O homossexual visto por entendidos. Rio de Janeiro: Garamond, 2004.

HATOUM, Milton. Saiu “Lampião”. Alegre, mas provocador. Revista Istoé, São Paulo, 19 abr. 1978

MAcRAE, Edward. A construção da igualdade: identidade sexual e política no Brasil da abertura. Campinas: UNICAMP, 1990.

MÍCCOLIS, Leila. Na hora da festa, conosco ninguém pode. Lampião da Esquina, Rio de Janeiro, p. 9-10, jan, 1980.

MISSE, Michel. O estigma do passivo sexual: um símbolo de estigma no discurso cotidiano. 3. ed. Rio de Janeiro: Booklin: NECVU: Le Metro, 2007. Disponível em: http://disciplinas.stoa.usp.br/pluginfile.php/291511/mod resource/content $/ 1 / \mathrm{O} \% 20 \mathrm{Estig}$ ma\%20sexual\%20-\%20Michel\%20Misse\%20\%281\%29.unlocked.pdf. Acesso em: 10 fev. 2015.

OLIVEIRA, Rosa Maria Rodrigues de. Direitos sexuais de LGBTTT no Brasil: jurisprudências, propostas legislativas e normatização federal. Brasília, DF: Governo Federal, 2012. Disponível em:

http://www.defensoria.sp.gov.br/dpesp/Repositorio/39/Documentos/Publicacao_DIREI TOS_sexuais_LGBTT_pdf. Acesso em: 15 maio 2015.

PARKER, Richard. Abaixo do Equador: culturas do desejo, homossexualidade masculina e comunidade gay no Brasil. Rio de Janeiro: Record, 2002.

PEDRO, Joana Maria; WOLFF, Cristina Scheibe. As dores e as delícias de lembrar a ditadura no Brasil: uma questão de gênero. História, São Leopoldo, v. 15, n. 3, p. 398405, 2011.

PENTEADO, Darcy. Começaram a nos entender: mas é isso o que nos interessa? Lampião da Esquina, Rio de Janeiro, p. 12, jun, 1980.

PERLONGHER, Nestor. Prosa plebeya: ensayos 1980-1992. Buenos Aires: Colihue, 2008.

POR QUE se é homossexual? Entender, Rio de Janeiro, n. 1, p. 1, 24 jul. 1977.

RODRIGUES, Jorge Caê. Impressões de identidade. Niterói: EDUFF, 2010.

SILVA, Aguinaldo. Aguinaldo Silva. Resistir é preciso. Disponível em:

https://www.youtube.com/watch?v=2z9uyCRF7ic. Acesso em: 10 maio 2014. 
SILVA, Claudio Roberto. Reinventando o sonho: história oral de vida política e homossexualidade no Brasil Contemporâneo. 1998. Dissertação (Mestrado em História) - Universidade de São Paulo, São Paulo, 1998.

SIMÕES, Júlio Assis. Antes das letrinhas: homossexualidade, identidades sexuais e política. In: COELHO, Clair Catilhos; LAGO, Mara Coelho de Souza; LISBOA, Teresa Kleba; TORNQUIST, Carmen Susana (org.). Leituras de resistência: corpo, violência e poder. Florianópolis: Mulheres, 2009. p. 215-242.

SOLIVA, Thiago Barcelos. A confraria gay: um estudo de sociabilidade, homossexualidade e amizades na Turma Ok. 2012. Dissertação (Mestrado em Sociologia e Antropologia) - Instituto de Filosofia e Ciências Sociais, Universidade Federal do Rio de Janeiro, Rio de Janeiro, 2012.

SOUTO MAIOR JÚNIOR, Paulo Roberto. "Assumir-se" ou não "assumir-se"? O Lampião da Esquina e as homossexualidades no Brasil. 2015. Dissertação (Mestrado em História) - Universidade Federal de Pernambuco, Recife, 2015.

SPENCER, Colin. Homossexualidade: uma história. Rio de Janeiro: Record, 1996.

TREVISAN, João Silvério. Devassos no paraíso: a homossexualidade no Brasil, da colônia à atualidade. São Paulo: Record, 2007.

UMA PESQUISA Manchete/Ibope, no Rio e em São Paulo, e uma pergunta:

Homossexualismo? Manchete, Rio de Janeiro, nov. 1975.

VERAS, Elias Ferreira; PEDRO, Joana Maria. Os silêncios de Clio: escrita da história e (in)visibilidade das homossexualidades no Brasil. Tempo e Argumento, Florianópolis, v. 6, n. 13, p. 90-109, set./dez. 2014.

Submetido em: 23.03.2017

Aprovado em: 01.02.2019 